\title{
History and class: a response to Palmer
}

\author{
Mao Mollona ${ }^{1}$
}

Published online: 13 September 2018

(C) The Author(s) 2018

Keywords Class $\cdot$ History $\cdot$ Political economy $\cdot$ Culture $\cdot$ Marxism $\cdot$ Gramsci

Palmer's inspiring piece considers the challenge of producing a working-class history attuned to the heterogeneous, subjective and sensuous forms of class struggle including their unconscious and affective dimensions. I admire the fluidity of the form of Palmer's narrative, its multidimensionality and personal involvement. The shift in Canadian labour history he describes - towards identitarian, aestheticised, affective and embodied forms of class analysis - reflects a well-known global trajectory, party associated to the global shift in political economy and the new complexity of contemporary forms of class articulation, and partly to the neo-liberalisation of academia. I am captured by how Palmer reframes this shift by focusing on the political unconscious. "How to turn the political unconscious of researching, writing and interpreting class into amore material conscious future in the field?" "How to turn the unknown, affective dimension of politics into a form of class consciousness - shared by scholars and activists?" "How to bridge political analysis and activism?"

The issue of intersectionality looms large in Palmer's analysis and I want to focus on it. I am particularly interested in the historically entanglement between class struggle and struggles for self-representation and in the deeply emotional, subjective and often unconscious processes of identification, dis-identification and stigma attached to them. I am interested in the grey zone where Eric Wolf's “people without history” (1982) meet Spivak's (1988) voiceless sati women and in the possible forms taken by their coming together in solidarity.

Looked at from the perspective of the long durèe, (Wolf 1982; Wallerstein 1983) capitalism is structurally entangled with the movement of colonisation and exploitation of the colonies and of physical and moral annihilation of the primitive other. The bourgeoisie's dream to live the aristocratic life by extracting surplus labour from inferior "others" and its self-perception of being "caste-like" (Balibar 1991) is asserted through violence in the colonies - and neocolonies. But "at home" capitalist profit is reproduced through the institutions of the factory and the (semi-proletarianised) household where rents are extracted in the form of surplus labour performed by racially or sexually inferior labourers. Thus, the international capitalist

Mao Mollona

m.mollona@gold.ac.uk

1 Department of Anthropology, Goldsmiths University of London, New Cross, London SE14, UK 
division of labour - between the productive work performed by the "core" and unproductive or domestic labour performed in the "periphery" —within the national borders materialises itself in the split between factory work and domestic labour (Mies 1982; Federici 2014). In this context, surplus extraction is made possible by racist and sexist ideologies that push the informal, domestic or black labourers outside history and render them voiceless.

Bringing together devalued domestic labourers and only partially commodified wageworkers, proletarianisation happens "despite" the capitalist and not because of them. Thus, the strength of capitalism is to reconcile the logic of slavery and the logic of the market-social death (Patterson 1982) and partial proletarianisation-by constructing an idea of "personhood" that obscures and precludes class identification. Because of the entanglement of economic exploitation and political marginalisation - as racial minorities under the colonial system or ethnic and sexual minorities under modern nation-states - proletarian struggles are as much economic as they are struggles for self-representation. This is an important methodological and conceptual issue. The history of class struggle cannot be understood without an appreciation of how marginal constituencies struggle to represent themselves as unique people and to be agents of self-determination. This is the lesson that we learn from the "proletarian histories" of the early Rancière (1982) or more recently, of Ross (2015).

Italian philosopher Antonio Gramsci describes this link between class struggle and selfrepresentation as a tension, contradictory and multi-layered, between class and culture. On the one hand, culture is hegemonic, because it presents the interests of the dominant classes as interests of the whole of society and ossifies them around a shared "common sense". But culture has also a special plastic property - an ability to outflow and expand beyond the material conditions in which it originates, connect to other social relations and encompass the point of view of "the other" (Gramsci 1978). In this light, culture is counter-hegemonic, that is constitutes a political movement away from economically specific locations - a jump from structure to superstructure which allows for novel forms of relationality to emerge. In its propensity to seek connections, mend separations and feel and experience the point of view of "the other" - bridging economic divides and cutting across classes - culture is a revolutionary weapon of the subaltern classes.

Indeed, class and culture are two central and antagonistic dimensions of the experience of capitalism - as of any social relation. Their relationship is temporally and spatially contingent on the broader structural context. Historically, industrialisation, nationalism, mass-production and state centralisation fostered the articulation of peoplehood along class lines. Whereas the financialisation of the economy, the flexibilisation of production, the deregulation of labour and the dissolution of the wage-contract within the global context of uneven development, contributed to the decline of class politics and the return of identitarian, nativist and cultural forms of political identification. Intended to valorise those human relations that are not contained within the rigid realm of wage-work, identity politics in fact, naturalised personhood within the rigid and timeless boundaries of "culture" while at the same time, reproduced the logic of capital - through medicalising discourses, bio-technology or sheer racism - within the very micro-texture of the individualised body.

For some reason Gramsci proved more popular among post-Marxist "southern" scholars than among western Marxists. The historiography of the "heirs of Gramsci" (Guha, Laclau and Hall — Perry Anderson 2016) — was meant to challenge the ethnocentrism of western Marxism proposing a broad socialist project which both valorised and encompassed cultural differences, including different narratives of class struggle. Undoubtedly this diasporic historiography (Hall, Laclau and Guha were exiled academics to the UK) was liberating. But, the cultural 
critique of capitalism anticipated and perhaps even triggered the neo-liberal shift of the 1980s. (Boltanski and Chiapello 2006; Meiksins Wood 1998).

By looking at the historical tensions between class and culture, we can make sense of the dramatic political transformations in recent years, namely the triumph of neo-liberalism and the recent populist turn. In a controversial article written on Marxism Today (1979) just a few months before Margaret Thatcher become the leader of the Tory Party, Jamaican scholar Stuart Hall denounces the "moral panic" of the white working-class about youth revolt, union activism and black immigration. But racism was not the only value that aligned the working-class with the petty bourgeoisie. They were both deeply disaffected with the bureaucratic and controlling statism and collectivism of the ruling Labour party. Thatcher would soon tap into this generalised culture of fear and discontent and discoursively frame her opposition to the Labour Party as a struggle of "the people" against the technocratic and centralist state.

Referring to Gramsci's notion of "passive revolution", Hall (1979) described the new capitalism of the 1980s as a project of "regressive modernisation" which combined "economical" and "cultural" aspects. For instance, Thatcher understood that by constructing a new economic narrative she could trigger a radical political change and that monetarism, the extreme version of free market economy proposed by Milton Friedman (at the time relatively unknown), could be used as an ideology for radical change. Already at the beginning of the 1980s, when very few people in the UK could predict the seismic shifts caused by the big-bang ${ }^{1}$ in the City of London, Thatcher understood that the ideology of monetarism would play a central political role - in breaking the trade unions, legitimising privatisation, attracting global finance - and built a new popular imaginary that wove together the contradictory positions and components of Torysm (family, authority and patriarchalism) with those of neo-liberalism (individualism, mobility, success, anti-statism, economic deregulation and global finance). Using the example of Thatcher's ideological appropriation of monetarism, Hall argued that the economy is a political and cultural construct — which caused him to clash with some of his comrades within the New Left Review (NLR) group. After all, was not the idea that economics is just a technical matter at the heart of the right-wing ideology of Thatcherism?

But in his book, Resistance Through Rituals, Hall and Jefferson (1975) shows that youth sub-cultures within the working-class resisted cooptation into petty bourgeois values. Indeed, as in the case of the struggles of operaismo in Italy in the 1970s, young immigrants were the most resilient section of the working-class in the UK, precisely because they struggled against capitalism on two fronts: one of cultural recognition and one of economic redistribution. According to Perry Anderson, Hall understood that modernity: "would have to be fought out across the whole space of civil society, as well as over the state, and could not afford to lapse into postures of indifference or disdain towards areas and issues traditionally regarded as less than political: gender, race, family, sexuality, education, consumption, leisure, nature as well as work, wages, taxes, health, or communication." (Anderson 2016).

The issue of cultural difference looms large in the recent raise of left-wing populism in Europe. In a conversation with the Errejon (the leader of Podemos) Mouffe and Errejon (2016) argues that Right-wing politicians have always been better Gramscians than Left-wing ones, who continues to focus on class struggles. In that piece Mouffe and Errejon congratulate themselves for having prefigured and even enacted a new Gramscian political imaginary in Spain. Sadly, in the course of just two years, things have radically changed. Podemos lost touch with the grassroot movements and working-class constituencies that propelled it to

${ }^{1}$ The deregulation of the credit market in the City of London. 
power and ended up supporting the corrupted socialist Party (PSOS) in the latest governmental reshuffle (a painful reminder of the Syriza experience in Greece). A racialised and morally loaded class discourse was re-appropriated by right-wing populists.

But there are some reasons for hope. The most important political movements emerged in the past years - the $8 \mathrm{M}$ movement in Europe, Indigenous activism against multinational corporations in Canada and Black Lives Matter in the US - combine economic demands and demands for cultural recognition and self-determination and in the process, generate new mew modes of grassroot theorising and historiography.

For instance, Marisa Perez (2018) from the Fundación de Los Comunes in Spain, describing the feminist demonstration of the 8th of March (which brought 5 million people in the street in Spain) as a "feminists' strike" proposes a new mode of address for feminism, reconnecting it to broader anti-capitalist struggles. How would a world without the reproductive labour of women look like? What kind of class solidarities would such form of address allow across sexes and genders? What consequences would have the de-commodification of domestic labour for labour struggles in general?

Philosopher Chantal Mouffe (Mouffe and Errejon 2016) argues that passion is a central dimension of contemporary politics. But, as I have showed, passion is not antithetic to the capitalist logic of interest (Hirschman 1977) because capitalism entitlements to profits are constructed along lines of race, sexuality, ethnicity and nationality that cut deep into our sense of humanity, undermine self-respect and preclude the empathic movement of culture that lead to class consciousness.

The gap between a growing underpaid, precarious and informalised working-class and an increasingly caste-like capitalist class has been widening for some time. According to sociologist Streeck, capitalism is heading towards its own dissolution because is unable to sustain the Polanyian compass between profit and social redistribution (2016). Indeed, capitalist privilege today is so exclusive that neither cultural hegemony nor social redistribution can obscure or legitimise it. Instead, such regime is enforced through generalised state violence and overt racism and sexism.

In such context where economic dispossession goes with the extreme devaluation of human lives, the experiences, both historical and present, of brutal marginalisation of people of colour, "illegal" migrants and women, are (even more) symptomatic of the broader human condition. An historiography attuned to the layered fault-lines of race, gender and ethnicity along which capitalism operates and constructs its narratives and to the intimate affects and raw passions that fuel capitalist interest can contribute to "the realisation of class as an active, conscious agent of struggle" as Palmer advocates, and to a new solidarity between the immanent agents of working-class history and those who continue to struggle to find a voice and presence in it.

Open Access This article is distributed under the terms of the Creative Commons Attribution 4.0 International License (http://creativecommons.org/licenses/by/4.0/), which permits unrestricted use, distribution, and reproduction in any medium, provided you give appropriate credit to the original author(s) and the source, provide a link to the Creative Commons license, and indicate if changes were made.

\section{References}

Anderson, P. 2016. The heirs of Gramsci in New Left Review. 100.

Balibar, E. 1991. Class Racism. In Race, nation, class. Ambiguous identities, ed. E. Balibar and I. Wallerstein. London: Verso.

Boltanski, L., and E. Chiapello. 2006. The new spirit of capitalism. London: Verso. 
Federici, S. 2014. Revolution at point zero. Housework, reproduction and feminist struggle. AP Press.

Gramsci, A. 1978. In Selections from the prison notebooks, ed. Q. Hoare and G. Nowell-Smith. London: Lawrence and Wishart.

Hall, S. 1979. Thatcherism a new stage? In Marxism Today.

Hall, Stuart, and Tony Jefferson, eds. 1975. Resistance through rituals: youth Sub-cultures in post-war Britain. London.

Hirschman, A. 1977. The passion and the interest. political arguments for capitalism before its triumph. Princeton University Press.

Meiksins Wood, E. 1998. The retreat from class. a "new" true socialism. London: Verso.

Mies, M. 1982. The lacemakers of Narsapur, Indian Housewives Produce for the World Market. London: Zed books.

Mouffe, C., and I. Errejon. 2016. Podemos, In the name of the people. London: Lawrence and Wishart.

Patterson, O. 1982. Slavery and social death. Cambridge: Harvard University Press.

Perez, M. 2018. Spain's feminist strike. In New left review, vol. 110, 35-38.

Rancière, J. 1982. Proletarian nights. The workers' dreams in nineteenth-century France. London: Verso.

Ross, K. 2015. Communal luxury. The political imaginary of the Paris commune. London: Verso.

Spivak, G. 1988. Can he subaltern speak? In Marxism and the interpretation of culture, ed. C. Nelson and L. Grossberg, 271-313. Basingstoke: Macmillan Education.

Streeck, W. 2016. How will capitalism end? London: Verso.

Wallerstein, I. 1983. Historical Capitalism. London: Verso.

Wolf, E. 1982. Europe and the people without history. Berkeley: University of California Press. 